\title{
Tolerance response of multidrug-resistant Salmonella enterica strains to habituation to Origanum vulgare $\mathrm{L}$. essential oil
}

\author{
Daniel F. M. Monte ${ }^{1}$, Adassa G. Tavares ${ }^{2}$, Allan R. Albuquerque ${ }^{3}$, Fábio C. Sampaio ${ }^{3}$, \\ Tereza C. R. M. Oliveira ${ }^{4}$, Octavio L. Franco ${ }^{5,6}{ }^{*}$, Evandro L. Souza ${ }^{2}$ and Marciane Magnani ${ }^{7}{ }^{*}$ \\ ${ }^{1}$ Department of Food Engineering, Center of Technology, Federal University of Paraiba, João Pessoa, Brazil \\ ${ }^{2}$ Department of Nutrition, Center of Health Sciences, Federal University of Paraiba, João Pessoa, Brazil \\ ${ }^{3}$ Department of Clinical and Social Dentistry, Center of Health Sciences, Federal University of Paraiba, João Pessoa, Brazil \\ ${ }^{4}$ Department of Food Science and Technology, Center of Agricultural Sciences, Londrina State University, Londrina, Brazil \\ ${ }^{5}$ Center of Biochemical and Proteomic Analysis, Catholic University of Brasilia, Brasilia, Brazil \\ ${ }^{6}$ S-Inova, Pós-Graduação em Biotecnologia, Universidade Católica Dom Bosco, Campo Grande, Brazil \\ ${ }^{7}$ Laboratory of Microbial Processes in Foods, Department of Food Engineering, Center of Technology, Federal University of Paraiba, João Pessoa, Brazil
}

\section{Edited by:}

Luis Cláudio Nascimento Da Silva, University of Copenhagen, Denmark

\section{Reviewed by:}

Atte Von Wright, University of Eastern Finland, Finland

Lei Dai, lowa State University of Science and Technology, USA

Tzi Bun Ng, The Chinese University of Hong Kong, China

Alexandre José Macedo, Universidade Federal do Rio Grande do Sul, Brazil

\section{*Correspondence:}

Octavio L. Franco, Center of

Biochemical and Proteomic Analysis, Catholic University of Brasilia, SGAN 916N, Modulo C, Avenida W5, Asa Norte, Sala 219, Brasilia, Distrito Federal, Brazil

e-mail: ocfranco@gmail.com; Marciane Magnani, Laboratory of Microbial Processes in Foods, Department of Food Engineering, Center of Technology, Federal University of Paraiba, Campus I, 58051-900 João Pessoa, Brazil e-mail:magnani2@gmail.com
Multidrug-resistant Salmonella enterica isolates from human outbreaks or from poultry origin were investigated for their ability to develop direct-tolerance or cross-tolerance to sodium chloride, potassium chloride, lactic acid, acetic acid, and ciprofloxacin after habituation in subinhibitory amounts $(1 / 2$ of the minimum inhibitory concentration $-1 / 2$ $(\mathrm{MIC}$ ) and $1 / 4$ of the minimum inhibitory concentration - 1/4 MIC) of Origanum vulgare $\mathrm{L}$. essential oil (OVEO) at different time intervals. The habituation of $S$. enterica to OVEO did not induce direct-tolerance or cross-tolerance in the tested strains, as assessed by the modulation of MIC values. However, cells habituated to OVEO maintained or increased susceptibility to the tested antimicrobials agents, with up to fourfold double dilution decrease from previously determined MIC values. This study reports for the first time the non-inductive effect of OVEO on the acquisition of direct-tolerance or cross-tolerance in multidrug-resistant $S$. enterica strains to antimicrobial agents that are largely used in food preservation, as well as to CIP, the therapeutic drug of salmonellosis.

Keywords: Salmonella, oregano, tolerance, ciprofloxacin, multidrug-resistant

\section{INTRODUCTION}

Salmonella enterica is recognized as the most frequent cause of foodborne disease in the world (Hendriksen et al., 2011; GomesNeto et al., 2014). Foodborne outbreaks caused by this pathogen are mainly associated with the consumption of chicken meat, eggs, and egg products (Kottwitz et al., 2010; Timme et al., 2012). A number of studies have shown that previous exposure of S. enter$i c a$ to a single stressful condition could result in homologous or heterologous tolerance and increasing subsequent resistance to the same or different environment stresses (Álvarez-Ordóñez et al., 2010; Dubois-Brissonnet et al., 2011; Shah et al., 2013). Salts and acids are traditionally used to process and preserve food, and these compounds impose stress conditions on bacterial cells to limit their growth and survival. However, it has been reported that the exposure of $S$. enterica to subinhibitory conditions imposed by these classical antimicrobial compounds can undergo genetic and physiologic changes. These changes allow the cells to become more resistant in subsequent exposures to the antimicrobial compounds, due to the development of a tolerance response (Álvarez-Ordóñez et al., 2012; Spector and Kenyon, 2012; Yang et al., 2014).

One of the concerns related to the increase of antimicrobial resistance in Salmonella is the reduction of the clinical efficacy of antibiotics, particularly the quinolones, resulting in treatment failure. Ciprofloxacin (CIP) is a $2^{\text {nd }}$ generation quinolone, is one of the first-choice agents used to treat salmonellosis. However, a significant rise in the number of Salmonella strains with reduced susceptibility to this antibiotic has been observed in humans and food involved outbreaks (Ferrari et al., 2013a; Rushdy et al., 2013; Ballesté-Delpierre et al., 2014).

Origanum vulgare L. essential oil (OVEO) has been cited as a potential compound to control the growth and survival of $S$. enterica in food (Gomes-Neto et al., 2014; Luz et al., 2014), due to strong anti-Salmonella activity, as shown in laboratory media and in food-mimicking models (Álvarez-Ordóñez et al., 2009; Luz et al., 2012). However, there is a lack of information regarding the effects of exposure to OVEO on the development of tolerance 
in multidrug-resistant $S$. enterica to antimicrobials traditionally used to prevent the infection of this bacterium in food industry or for therapeutic treatment of salmonellosis. Knowledge about the magnitude of tolerance induction in foodborne pathogens, particularly in S. enterica, which possesses a large diversity of resistance mechanisms (Spector and Kenyon, 2012), must be a requisite for the development of anti-bacterial compounds, such as OVEO, that are considered for application in food preservation systems.

Considering these aspects, the aim of this study was to assess the effects of the exposure of multidrug-resistant epidemic S. enterica strains to subinhibitory concentration of OVEO for different time intervals on the development of bacterial tolerance to salts and organic acids used by the food industry, as well to CIP, a therapeutic drug of human salmonellosis.

\section{MATERIALS AND METHODS ESSENTIAL OIL AND ANTIMICROBIALS AGENTS}

The antimicrobial agents used in this study were OVEO (Laszlo Aromaterapia Ltda., Minas Gerais, Brazil), CIP (Oxoid, UK), sodium chloride ( $\mathrm{NaCl}$ P.A.), potassium chloride $(\mathrm{KCl})$, glacial acetic acid (AA), and lactic acid (LA, 85\%; Vetec Ltda., Rio de Janeiro, Brazil). According to the technical report presented by the supplier, carvacrol is the most prevalent compound in the OVEO assayed in this study $(66.1 \mathrm{~g} / 100 \mathrm{~mL})$, followed for $p$-cymene $(12.4 \mathrm{~g} / 100 \mathrm{~g})$ and $\gamma$-terpinene $(8.3 \mathrm{~g} / 100 \mathrm{~g})$. OVEO solutions $\left(40-0.3 \mu \mathrm{L} \mathrm{mL}^{-1}\right)$ were prepared in sterile brain heart infusion (BHI) broth (Himedia, India) and Tween 80 (1\%; Sigma-Aldrich, USA) was added as an emulsifier. Preliminary test were conducted to ensure that the antibacterial activity was because of the OVEO and not Tween 80 . The results demonstrated that Tween 80 at the given concentration did not inhibit the growth of the assayed bacterial strains cultivated in $\mathrm{BHI}$ broth. Solutions of $\mathrm{NaCl}(600$ $\left.50 \mathrm{mg} \mathrm{mL}^{-1}\right), \mathrm{KCl}\left(600-50 \mathrm{mg} \mathrm{mL}^{-1}\right), \mathrm{AA}\left(160-1.25 \mu \mathrm{L} \mathrm{mL}^{-1}\right)$, and LA (160-1.25 $\left.\mu \mathrm{L} \mathrm{mL}^{-1}\right)$ were prepared in sterile BHI broth.

\section{TEST STRAIN}

The test microorganisms used in this study included S. Enteritidis 209, isolated from feces of outbreak patient, $S$. Typhimurium 149 , isolated from food involved in outbreak and $S$. Corvallis 297 isolated from poultry (chicken hens). The strains were resistant to aminoglycosides (gentamicin and streptomycin); $\beta$-lactams (ampicillin and cefotaxime); quinolones (norfloxacin and nalidixic acid), and sulphametoxazole-trimethoprim. The strains were characterized according to their quinolone resistance mechanism(s) as described in Table 1 (Souza et al., 2011; Ferrari et al., 2013a,b). Stock cultures were kept at $4 \mathrm{C}$ before use. Each strain was grown in $\mathrm{BHI}$ broth at $37^{\circ} \mathrm{C}$ for $18 \mathrm{~h}$ (late exponential growth phase), harvested by centrifugation $\left(4500 \mathrm{~g}, 15 \mathrm{~min}, 4^{\circ} \mathrm{C}\right)$, washed twice in sterile saline solution $(\mathrm{NaCl}, 0.85 \%)$, and resuspended in sterile saline solution to obtain standard cell suspensions at which the OD reading at $660 \mathrm{~nm}\left(\mathrm{OD}_{660}\right)$ was 0.1 (c.a. $10^{7} \mathrm{CFU} \mathrm{mL}^{-1}$; McMahon et al., 2008).

\section{DETERMINATION OF MINIMUM INHIBITORY CONCENTRATION (MIC)}

A modified microtiter plate assay was used to determine the MIC of OVEO, NaCl, KCl, AA, LA, and CIP (Sarker et al., 2007).

\begin{tabular}{|c|c|c|c|}
\hline Test strains & $\begin{array}{l}\text { Resistance } \\
\text { mechanism* }\end{array}$ & $\begin{array}{l}\text { MIC** of OVEO } \\
\left(\mu \mathrm{mL}^{-1}\right)\end{array}$ & $\begin{array}{l}\text { MIC* of CIP } \\
\left(\mu \mathrm{L} \mathrm{mL}^{-1}\right)\end{array}$ \\
\hline \multirow[t]{2}{*}{ S. Enteritidis 209} & $\begin{array}{l}\text { Ser 83-Tyr gyrA } \\
\text { gene mutation }\end{array}$ & 2.5 & 0.12 \\
\hline & $\begin{array}{l}\text { Active AcrAB-TolC } \\
\text { system }\end{array}$ & 0 & 0 \\
\hline S. Typhimurium 149 & $\begin{array}{l}\text { Ser 83-Tyr gyrA } \\
\text { gene mutation }\end{array}$ & 2.5 & 0.12 \\
\hline S. Corvallis 297 & $\begin{array}{l}\text { PMRQ- qnrB1 } \\
\text { plasmidial gene }\end{array}$ & 5 & 0.5 \\
\hline
\end{tabular}

* Resistance Mechanism previously characterized by Souza et al. (2011) and Ferrari etal. (2013a,b); **MIC: Minimum Inhibitory Concentration; OVEO, O. vulgare L. essential oil; CIP, cirpofloxacin.

The 96-well plates were prepared by dispensing $90 \mu \mathrm{L}$ of OVEO (40-0.31 $\left.\mu \mathrm{L} \mathrm{mL}^{-1}\right)$, salts $\left(600-50 \mathrm{mg} \mathrm{mL}^{-1}\right)$, acids $(16-0.125$ $\left.\mu \mathrm{L} \mathrm{mL}^{-1}\right)$, or CIP solutions $\left(0.005 \mu \mathrm{L} \mathrm{mL}^{-1}\right.$ to $\left.1 \mu \mathrm{L} \mathrm{mL}^{-1}\right)$ into $90 \mu \mathrm{L}$ of double-concentration BHI broth in each well. Finally,

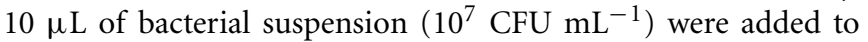
each well. The microplate was wrapped loosely with cling wrap to prevent bacterial dehydration and ensure that OVEO would not volatilize. Each plate included controls without the antimicrobial test agents. The plates were prepared in triplicate, and they were statically incubated at $37^{\circ} \mathrm{C}$ for $24 \mathrm{~h}$ in a microplate incubator/reader (EON model, Biotek Inc., USA). Following incubation, MIC values were confirmed as the lowest concentrations of OVEO, $\mathrm{NaCl}, \mathrm{KCl}, \mathrm{AA}, \mathrm{LA}$, or CIP at which the $\mathrm{OD}_{660}$ was less than 0.01 (McMahon et al., 2008). Breakpoints that were designed by Clinical and Laboratory Standards Institute (CLSI), (2012) were used to interpret MIC values of CIP [Clinical and Laboratory Standards Institute (CLSI), 2012]. All MIC determination assays were performed in triplicate and in three separate experiments. The results were expressed as modal values because no variation was observed between the replicated results (McMahon et al., 2007).

\section{EVALUATION OF INDUCTION OF BACTERIAL DIRECT-TOLERANCE AND BACTERIAL CROSS-TOLERANCE}

The induction of direct-tolerance and cross-tolerance was performed by exposing the test strains to subinhibitory OVEO concentrations for different time intervals, followed by a determination of the MIC values for the homologous stressing agent (OVEO) or heterologous stressing agents $(\mathrm{NaCl}, \mathrm{KCl}, \mathrm{AA}, \mathrm{LA}$, and CIP; Luz etal., 2012). For this test, $4 \mathrm{~mL}$ of BHI broth was inoculated with $1 \mathrm{~mL}$ of bacterial suspension (c.a. $10^{7} \mathrm{CFU}$ $\left.\mathrm{mL}^{-1}\right)$. Appropriate amounts of OVEO was added to obtain the desired final concentration ( $1 / 2$ MIC or $1 / 4 \mathrm{MIC}$ ), followed by static incubation at $37^{\circ} \mathrm{C}$. After 24,48 , and $72 \mathrm{~h}$ of incubation, an aliquot of each system was taken (standardized to

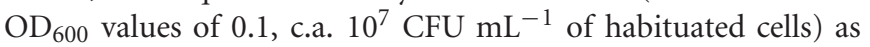
inoculum $(10 \mu \mathrm{L})$ to determine the MIC of OVEO, or MIC of 
$\mathrm{NaCl}, \mathrm{KCl}, \mathrm{AA}$, and LA using the same microtiter plate assay as described before (Sarker et al., 2007). The induction of directtolerance and cross-tolerance in bacteria was tested by comparing the MIC values of OVEO or $\mathrm{NaCl}, \mathrm{KCl}, \mathrm{AA}, \mathrm{LA}$, and CIP against those of the tested strains before and after the habituation treatment with subinhibitory amounts of OVEO. Control systems without OVEO exposure were similarly tested (nonhabituation treatment). All assays were performed in triplicate in three separate experiments, and the results were expressed as modal or median values. Only the modal values were presented in those experiments yielding same results (McMahon et al., 2007). Significant differences $(P<0.05)$ for induction of tolerance were considered when changes in MIC values were equal to or higher than a twofold increase ( $\geq$ twofold increase; Hammer et al., 2012).

\section{RESULTS}

The MIC values of OVEO against the tested strains ranged from $2.5 \mu \mathrm{L} \mathrm{mL} L^{-1}$ to $5 \mu \mathrm{L} \mathrm{mL} \mathrm{m}^{-1}$. Lower susceptibility to OVEO was observed in S. Corvallis 297 compared to S. Enteritidis 209 and S. Typhimurium 149 (Table 1). MIC of CIP ranged from $0.12 \mu \mathrm{L} \mathrm{mL} \mathrm{m}^{-1}$ to $0.5 \mu \mathrm{L} \mathrm{mL}-1$, which is considered to be a phenotype of reduced susceptibility to CIP according to the breakpoints designed by Clinical and Laboratory Standards Institute (CLSI), (2012). Similar to OVEO, the highest MIC of CIP was also observed against $S$. Corvallis 297. $\mathrm{NaCl}, \mathrm{KCl}, \mathrm{AA}$, and LA yielded MIC values of $150 \mathrm{mg} \mathrm{mL}^{-1}, 200 \mathrm{mg} \mathrm{mL}^{-1}, 2.5 \mu \mathrm{L}$ $\mathrm{mL}^{-1}$, and $10 \mu \mathrm{L} \mathrm{mL} L^{-1}$, respectively, against all the assayed strains.

The habituation of the strains to OVEO during the assessed time-intervals $(24,48$, and $72 \mathrm{~h}$ ) caused a decrease in MIC values of all strains studied. Regardless of the tested Salmonella strain and the OVEO concentration used for habituation ( $1 / 2$ MIC or $1 / 4$ MIC; Table 2), there was no induction of direct-tolerance in the bacterial cells for $72 \mathrm{~h}$. The maximum decrease in MIC value of OVEO (fourfold double dilution) was observed in $S$. Corvallis ( $5 \mu \mathrm{L} \mathrm{mL}^{-1}$ to $0.3 \mu \mathrm{L} \mathrm{mL}^{-1}$; Table 2 ). The decreased MIC values of OVEO against habituated S. enterica was related to the time of exposure to subinhibitory concentrations of OVEO because, with exception of $S$. Typhimurium 149 habituated to $1 / 4$ MIC of OVEO, the smallest MIC values were generally found against cells that were pre-exposed to OVEO for $72 \mathrm{~h}$ when compared with nonhabituated. During all the assessed time intervals, the MIC values of OVEO against non-habituated cells ranged from $5 \mu \mathrm{L} \mathrm{mL}^{-1}$ to $2.5 \mu \mathrm{L} \mathrm{mL}^{-1}$.

Similar to the direct-tolerance results, $\mathrm{MIC}$ values for $\mathrm{NaCl}$, $\mathrm{KCl}, \mathrm{AA}$, and LA against the OVEO-habituated cells were the same or decreased (one to threefold double dilution), when compared with MIC values against non-habituated cells (Tables 2 and 3). There was no effect of time-of-habituation to OVEO on the sensitivity of the habituated cells to $\mathrm{NaCl}, \mathrm{KCl}$, and LA. However, the decrease in MIC values of AA against habituated-cells always occurred after $72 \mathrm{~h}$ of exposure to subinhibitory concentration of OVEO. MIC values of CIP against the habituated cells were maintained when compared with the previously determined MIC values, indicating that habituation to OVEO did not alter the sensitivity of the strains to CIP. A transient decrease (two-fold

\begin{tabular}{|c|c|c|c|c|}
\hline \multirow[t]{2}{*}{ Strains } & \multirow[t]{2}{*}{ Treatment } & \multicolumn{3}{|c|}{$\operatorname{MIC}\left(\mu \mathrm{LL}^{-1}\right)$} \\
\hline & & $24 h^{*}$ & $48 h^{*}$ & $72 \mathrm{~h} *$ \\
\hline \multirow[t]{4}{*}{ S. Enteritidis 209} & Control $(0 \mu \mathrm{L}$ & 2.5 & 2.5 & 2.5 \\
\hline & OVEO $\mathrm{mL}^{-1}$ ) & & & \\
\hline & $\begin{array}{l}1 / 2 \text { MIC OVEO }(1.25 \mu \mathrm{L} \\
\left.\text { OVEO } \mathrm{mL}^{-1}\right)\end{array}$ & 2.5 & 1.25 & 0.3 \\
\hline & $\begin{array}{l}1 / 4 \mathrm{MIC} \text { OVEO }(0.6 \mu \mathrm{L} \\
\left.\text { OVEO } \mathrm{mL}^{-1}\right)\end{array}$ & 2.5 & 1.25 & 0.3 \\
\hline S. Typhimurium & Control $(0 \mu \mathrm{L}$ & 2.5 & 2.5 & 2.5 \\
\hline \multirow[t]{3}{*}{149} & OVEO $\mathrm{mL}^{-1}$ ) & & & \\
\hline & $\begin{array}{l}1 / 2 \text { MIC OVEO }(1.25 \mu \mathrm{L} \\
\left.\text { OVEO } \mathrm{mL}^{-1}\right)\end{array}$ & 1.25 & 1.25 & 0.6 \\
\hline & $\begin{array}{l}1 / 4 \mathrm{MIC} \text { OVEO }(0.6 \mu \mathrm{L} \\
\left.\text { OVEO } \mathrm{mL}^{-1}\right)\end{array}$ & 2.5 & 2.5 & 2.5 \\
\hline \multirow[t]{3}{*}{ S. Corvallis 297} & $\begin{array}{l}\text { Control }(0 \mu \mathrm{L} \\
\left.\text { OVEO } \mathrm{mL}^{-1}\right)\end{array}$ & 5 & 5 & 5 \\
\hline & $\begin{array}{l}1 / 2 \text { MIC OVEO }(2.5 \mu \mathrm{L} \\
\left.\text { OVEO } \mathrm{mL}^{-1}\right)\end{array}$ & 2.5 & 1.25 & 0.3 \\
\hline & $\begin{array}{l}1 / 4 \mathrm{MIC} \text { OVEO }(1.25 \mu \mathrm{L} \\
\left.\text { OVEO } \mathrm{mL}^{-1}\right)\end{array}$ & 2.5 & 2.5 & 2.5 \\
\hline
\end{tabular}

*Hours of previous habituation or not in the assayed sublethal concentrations of O. vulgare L. essential oil; MIC, minimum inhibitory concentration; OVEO, $O$. vulgare L. essential oil.

double dilution) of MIC values of CIP against S. Enteritidis 209 was observed after $48 \mathrm{~h}$ of habituation to $1 / 2 \mathrm{MIC}$ and $1 / 4 \mathrm{MIC}$ of OVEO.

\section{DISCUSSION}

Salmonella enterica presents a dynamic interaction with host and environment and has a high genetic variability related to the development of different antimicrobial resistance mechanisms (Ferrari et al., 2013a; Du etal., 2014). The serovars S. Enteritidis and $S$. Typhimurium are frequently cited as more tolerant to many antimicrobials agents when compared to other Salmonella serovars (Souza et al., 2011; Ferrari et al., 2013b; Ballesté-Delpierre et al., 2014). However, in the present study MIC values of OVEO and CIP were higher against $S$. Corvallis 297 when compared to the values against $S$. Enteritidis 209 and $S$. Typhimurium 149. The presence of qnrB19 gene in S. Corvalis 297 (Ferrari et al., 2013a), a wellknown mechanism of resistance to quinolone in Salmonella, could be related to the higher tolerance of the strains to the substances that were tested.

Salmonella Corvallis 297 showed the most decrease (fourfold double dilution) in MIC values of OVEO after habituation for $72 \mathrm{~h}$ and was the only strain that exhibited a significant decrease [more than onefold double dilution; Clinical and Laboratory Standards Institute (CLSI), 2012] in MIC of $\mathrm{NaCl}$ and this decrease occurred at the $24 \mathrm{~h}$ time point 


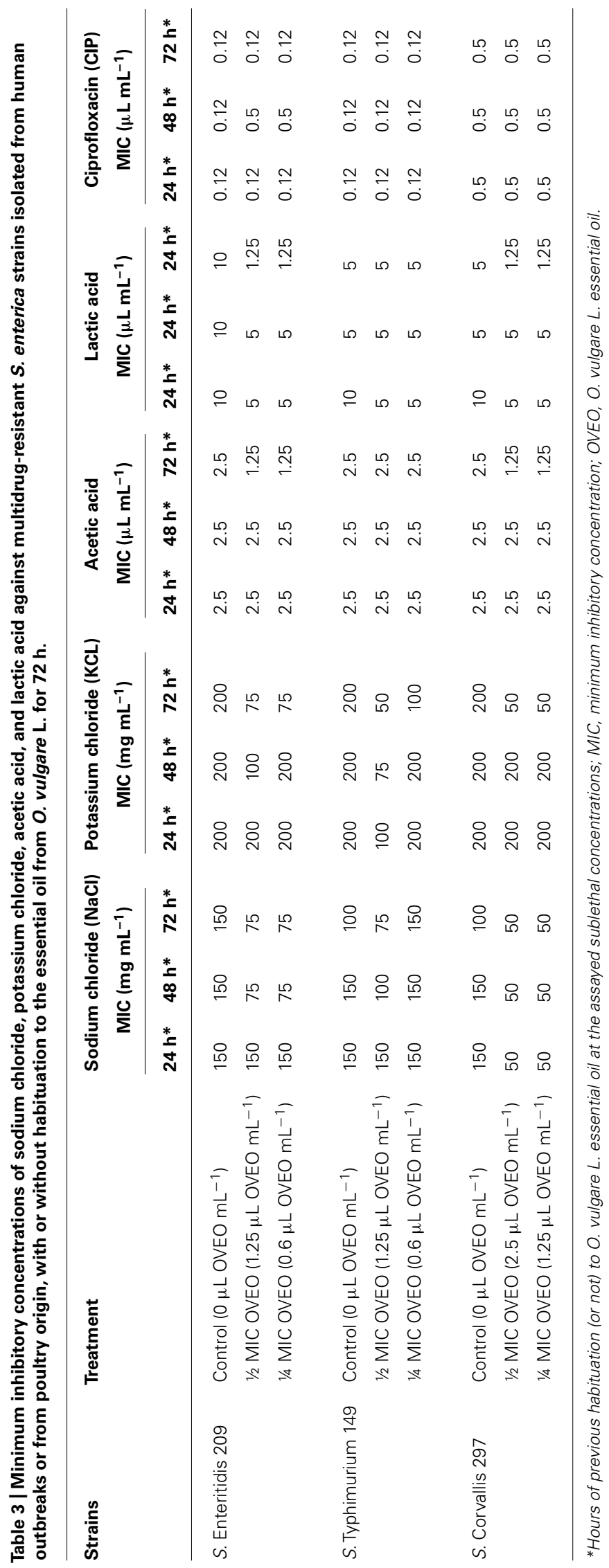


(Tables 1 and 2). The behavior of $S$. Corvallis could be associated with the low expression of AcrAB-TolC efflux pump related genes that has been previously described in this strain (Ferrari et al., 2013b). AcrAB-TolC is a well-known efflux system in S. enterica which is able to help in extrusion of bile salts, lipophilic antibiotics, dyes, detergents, and solvents from the cell. The expression of genes related to this efflux system has been associated with multiple-drug resistance (Spector and Kenyon, 2012), which is observed among the Salmonella strains assayed in this study. However, this explanation is in contrast with the behavior of S. Enteritidis 209, in which, despite high expression levels of AcrAB-TolC efflux pump related genes, the sensitivity to OVEO was increased (threefold double dilution decrease in MIC value) but the sensitivity to $\mathrm{NaCl}$ remained unaltered after habituation (Ferrari et al., 2013b). Changes in the cell wall structure and increased membrane permeability have been observed in Gram-negative bacteria that were exposed to sublethal concentrations of OVEO (Souza et al., 2013). These alterations in membrane structure, caused by the exposure to OVEO, could have affected the osmoregulation ability of the membrane or its capacity to extrude toxic materials and, therefore, increased the sensitivity of the tested Salmonella strains to OVEO, salts and acids. Changes in the cellular membrane fatty acids composition of $S$. Typhimurium that were subjected to habituation to OVEO at subinhibitory concentrations have been reported earlier (Luz etal., 2014). Even if an adaptation-response related changes in membrane occurred in the tested strains, these changes were not capable of causing obvious increase ( $\geq$ twofold doubling dilution; Hammer et al., 2012) in MIC values of OVEO, salts and acids, and therefore, conferring the development of direct-tolerance or cross-tolerance. In this study, non-induction of cross-tolerance to salts and acids after habituation to OVEO is noteworthy because the development of homologous and heterologous tolerance in S. enterica that were challenged with subinhibitory conditions, provided by other antimicrobial compounds or procedures used for controlling microbial growth and survival in foods, has already been documented (Dubois-Brissonnet et al., 2011). Previous studies have found development of crosstolerance in S. enterica after habituation to LA (Leyer and Johnson, 1993), AA (Álvarez-Ordóñez et al., 2009, 2012), NaCl, and KCl (Greenacre and Brocklehurst, 2006).

Maintenance of susceptibility to CIP after exposure to OVEO for an extended period was noticeable in the tested Salmonella strains. The multidrug-resistant phenotypes of these strains, with resistance to a variety of antibiotic classes that target different cellular components including the cell membrane, make this observation distinctive. Changes in antibiotic susceptibility in $S$. Typhimurium ST11 and S. Enteritidis NCTC 12694 after habituation to subinhibitory concentrations of Melaleuca alternifolia L. essential oil have been reported earlier. These changes in antibiotic susceptibility were associated with increase ( $\geq$ twofold double dilution) in MIC values of gentamicin, erythromycin, chloramphenicol, tetracycline, streptomycin, and trimethoprim (McMahon et al., 2008).

To our knowledge, this is the first study that investigated the tolerance development by multidrug-resistant $S$. enterica strains after habituation to subinhibitory concentrations of OVEO. These results revealed that habituating $S$. enterica strains to subinhibitory amounts of OVEO maintained or increased susceptibility to the same stressing agent and also to the tested heterologous stressing agents $(\mathrm{NaCl}, \mathrm{KCl}, \mathrm{LA}, \mathrm{AA}$, and $\mathrm{CIP})$.

\section{ACKNOWLEDGMENTS}

The authors are grateful to the National Council for Scientific and Technological Development (CNPq, Brazil) for financial support, and the Coordination of Improvement of Higher Education Personnel (CAPES, Brazil) for scholarship to the first (Daniel F. M. Monte) and second author (Adassa G. Tavares).

\section{REFERENCES}

Álvarez-Ordóñez, A., Fernández, A., Bernardo, A., and López, M. (2009). A comparative study of thermal and acid inactivation kinetics in fruit juices of Salmonella enterica serovar Typhimurium and Salmonella enterica serovar Senftenberg grown at acidic conditions. Foodborne Pathog. Dis. 6, 1147-1155. doi: 10.1089/fpd.2009.0313

Álvarez-Ordóñez, A., Fernández, A., Bernardo, A., and López, M. (2010). Arginine and lysine decarboxylases and the acid tolerance response of Salmonella Typhimurium. Int. J. Food Microbiol. 136, 278-282. doi: 10.1016/j.ijfoodmicro.2009.09.024

Álvarez-Ordóñez, A., Prieto, M., Bernardo, A., Hill, C., and López, M. (2012). The acid tolerance response of Salmonella spp: an adaptive strategy to survive in stressful environments prevailing in foods and the host. Food Res. Int. 45, 482-492. doi: 10.1016/j.foodres.2011.04.002

Ballesté-Delpierre, C., Solé, M., Domènech, O., Borrell, J., Vila, J., and Fàbrega, A. (2014). Molecular study of quinolone resistance mechanisms and clonal relationship of Salmonella enterica clinical isolates. Int. J. Antimicrobial Agents 43, 121-125. doi: 10.1016/j.ijantimicag.2013.08.017

Clinical and Laboratory Standards Institute (CLSI). (2012). "Performance standard for antimicrobial susceptibility testing," in Twenty-Second Information Supplement, Vol. 32. Wayne: CLSI/NCCLS.

Du, D., Wang, Z., James, N. R., Voss, J. E., Klimontt, E., and Ohene-Agyei, T., et al. (2014). Structure of the AcrAB-TolC multidrug efflux pump. Nature 509, 512-515. doi: 10.1038/nature13205

Dubois-Brissonnet, F., Naïtali, M., Mafu, A. A., and Briandet, R. (2011). Induction of fatty acid composition modifications and tolerance to biocides in Salmonella enterica serovar Typhimurium by plant-derived terpenes. Appl. Environ. Microbiol. 77, 906-910. doi: 10.1128/AEM.01480-10

Ferrari, R. G., Galiana, A., Cremades, R., Rodrígues, J. C., Magnani, M., Tognin, M. C. B., et al. (2013a). Plasmid-mediated quinolone resistance (PMQR) and mutations in the topoisomerase genes of Salmonella enterica strains from Brazil. Braz. J. Microbiol. 44, 657-662. doi: 10.1590/S1517-83822013000 200046

Ferrari, R. G., Galiana, A., Cremades, R., Rodrígues, J. C., Magnani, M., Tognin, M. C. B., etal. (2013b). Expression of the marA, soxS, acrB and ramA genes related to the AcrAB/TolC efflux pump in Salmonella enterica strains with and without quinolone resistance-determining regions gyrA gene mutations. Braz. J. Infect. Dis. 17, 125-130. doi: 10.1016/j.bjid.2012. 09.011

Gomes-Neto, N. J., Luz, I. S., Franco, O. L., Magnani, M., and Souza, E. L. (2014). Tolerance evaluation of Salmonella enterica serovar Typhimurium by exposure of subinhibitory amounts of Rosmarinus officinalis L. essential oil and 1,8-cineole in meat-model. Int. J. Food Sci. Tech. 49, 1912-1917. doi: 10.1111/ijfs. 12522

Greenacre, E. J., and Brocklehurst, T. F. (2006). The acetic tolerance response induces cross-protection to salt stress in Salmonella Typhimurium. Int. J. Food. Microbiol. 112, 62-65. doi: 10.1016/j.ijfoodmicro.2006.05.012

Hammer, K. A., Carson, C. F., and Riley, T. V. (2012). Effects of melaleuca alternifolia (Tea Tree) essential oil and the major monoterpene component terpinen-4-ol on the development of single- and multistep antibiotic resistance and antimicrobial susceptibility. Antimicrob. Agents Chemother. 56, 909-915. doi: 10.1128/AAC.05741-11

Hendriksen, R. S., Vieira, A. R., Karlsmose, S., Lo-Fo-Wong, D. M., Jensen, A. B., Wegener, H. C., et al. (2011). Global monitoring of Salmonella serovar distribution from the world health organization global foodborne infections network 
country data bank: results of quality assured laboratories from 2001 to 2007 . Foodborne Pathog. Dis. 8, 887-900. doi: 10.1089/fpd.2010.0787

Kottwitz, L. B. M., Oliveira, T. C. R. M., Alcocer, I., Farah, S. M. S. S., Abrahão, W. S. M., and Rodrigues, D. P. (2010). Epidemiologic data of salmonellosis outbreaks occurred between 1999 and 2008 in in Paraná State, Brazil. Acta Scientiarum. 32, 9-15.

Leyer, G. J., and Johnson, E. A. (1993). Acid adaptation induces cross-protection against environmental stresses in Salmonella Typhimurium. Appl. Environ. Microbiol. 59, 1842-1847.

Luz, I. S., Gomes-Neto, N. J., Tavares, A. G., Nunes, P. C., Magnani, M., and Souza, E. L. (2012). Evidence for lack of acquisition of tolerance in Salmonella enterica Serovar Typhimurium ATCC 14028 after exposure to sub-inhibitory amounts of Origanum vulgare L. essential oil and carvacrol. Appl. Environ. Microbiol. 78, 5021-5024. doi: 10.1128/AEM.00605-12

Luz, I. S., Melo, A. N., Bezerra, T. K., Madruga, M., Magnani, M., and Souza, E. L. (2014). Subinhibitory amounts of Origanum vulgare L. essential oil and carvacrol cause injury and changes in membrane fatty acid of Salmonella Typhimurium cultivated in a meat broth. Foodborne Pathog. Dis. 11, 357-361. doi: $10.1089 /$ fpd.2013.1695

McMahon, M. A. S., Blair, I. S., Moore, J. E., and McDowell, D. A. (2007). Habituation to sub-lethal concentrations of tea tree oil (Melaleuca alternifolia) is associated with reduced susceptibility to antibiotics in human pathogens. J. Antimicrob. Chemother. 59, 125-127. doi: 10.1093/jac/dkl443

McMahon, M. A. S., Tunney, M. M., Moore, J. E., Blair, I. S., and Gilpin, D. F. (2008). Changes in antibiotic susceptibility in staphylococci habituated to sublethal concentrations of tea tree oil (Melaleuca alternifolia). Lett. Appl. Microbiol. 47, 263-268. doi: 10.1111/j.1472-765X.2008.02420.x

Rushdy, A. A., Mabrouk, M. I., Abu-Sef, F. A., Kheiralla, Z. H., Mohamed, A. S., and Saleh, N. M. (2013). Contribution of different mechanisms to the resistance to fluoroquinolones in clinical isolates of Salmonella enterica. Braz. J. Infect. Dis. 4, 431-437. doi: 10.1016/j.bjid.2012.11.012

Sarker, S. D., Nahar, L., and Kumarasamy, Y. (2007). Microtitre plate-based antibacterial assay incorporating resazurin as an indicator of cell growth, and its application in the in vitro antibacterial screening of phytochemicals. Methods 42, 321-324. doi: 10.1016/j.ymeth.2007.01.006

Shah, J., Desai, P. T., Chen, D., Stevens, J. R., and Weimer, B. C. (2013). Preadaptation to cold stress in Salmonella enterica serovar Typhimurium increases survival during subsequent acid stress exposure. Appl. Environ. Microbiol. 79, 7281-7289. doi: 10.1128/AEM.02621-13
Souza, E. L., Azerêdo, G. A., Sousa, J. P., Figueiredo, R. C. B. Q., and Stamford, T. L. (2013). Cytotoxic effects of Origanum vulgare L. and Rosmarinus officinalis L. essential oils alone and combined at subinhibitory amounts on Pseudomonas fluorescens in a vegetable broth. J. Food Saf. 33, 163-171. doi: 10.1111/ jfs. 12036

Souza, R. B., Magnani, M., Ferrari, R. G., Kottwitz, L. B. M., Sartori, D., Tognim, M. C. B., et al. (2011). Detection of quinolone-resistance mutations in Salmonella spp. strains of epidemic and poultry origin. Braz. J. Microbiol. 42, 211-215. doi: 10.1590/S1517-83822011000100026

Spector, M. P., and Kenyon, W. J. (2012). Resistance and survival strategies of Salmonella enterica to environmental stresses. Food Res. Int. 45, 455-481. doi: 10.1016/j.foodres.2011.06.056

Timme, R. E., Allard, M. W., Luo, Y., Strain, E., Pettengill, J., Wang, C., et al. (2012). Draft genome sequences of 21 Salmonella enterica serovar Enteritidis strains. J. Bacteriol. 194, 5994-5995. doi: 10.1128/JB.01289-12

Yang, Y., Khoo, W. J., Zheng, Q., Chung, H. J., and Yuk, H. G. (2014). Growth temperature alters Salmonella Enteritidis heat/acid resistance, membrane lipid composition and stress/virulence related gene expression. Int. J. Food Microbiol. 172, 102-109. doi: 10.1016/j.ijfoodmicro.2013.12.006

Conflict of Interest Statement: The authors declare that the research was conducted in the absence of any commercial or financial relationships that could be construed as a potential conflict of interest.

Received: 13 September 2014; accepted: 02 December 2014; published online: 19 December 2014.

Citation: Monte DFM, Tavares AG, Albuquerque AR, Sampaio FC, Oliveira TCRM, Franco OL, Souza EL and Magnani M (2014) Tolerance response of multidrug-resistant Salmonella enterica strains to habituation to Origanum vulgare L. essential oil. Front. Microbiol. 5:721. doi: 10.3389/fmicb.2014.00721

This article was submitted to Antimicrobials, Resistance and Chemotherapy, a section of the journal Frontiers in Microbiology.

Copyright (C) 2014 Monte, Tavares, Albuquerque, Sampaio, Oliveira, Franco, Souza and Magnani. This is an open-access article distributed under the terms of the Creative Commons Attribution License (CC BY). The use, distribution or reproduction in other forums is permitted, provided the original author(s) or licensor are credited and that the original publication in this journal is cited, in accordance with accepted academic practice. No use, distribution or reproduction is permitted which does not comply with these terms. 